\section{The Accountant's Perception of the Usefulness of Financial Information in Decision Making - A Study in Portugal}

\author{
Catarina Libório Morais Cepêda ${ }^{1}$ \\ ${ }^{1}$ Polytechnic of Porto, Porto Accounting \\ and Business School, Porto, Portugal.
}

\author{
Albertina Paula Monteiro ${ }^{2}$ \\ ${ }^{2}$ Institute of Accounting and Administration \\ of Porto, Porto, Portugal.
}

Recebimento:

06/21/2019

Aprovação:

$11 / 28 / 1019$

Editor responsável:

Prof. Dr. Javier Montoya Del Corte

Avaliado pelo sistema:

Double Blind Review

\begin{abstract}
Purpose - This paper aims to analyse the factors that make Financial Information (FI) useful for decision making processes, from the perspective of Certified Accountants (CAs).
\end{abstract}

Design/methodology/approach - Following a quantitative methodological approach, a survey was applied to a sample of 157 CAs to empirically test the conceptual model.

Findings - The study finds that managers of larger and older firms, with better performance and with more complete Financial Statements (FSs) attribute greater usefulness to FI in decision making. The results also show that managers who are not the owner, who have academic qualifications at the higher education level, and have management skills attribute greater usefulness to FI in decision making.

Originality/value - The results of the study will guide accounting professionals in relation to the FI to be prepared within the scope of their duties, taking into account the characteristics of the company and the manager.

Keywords - Accounting, certified accountants, financial information, decision making.

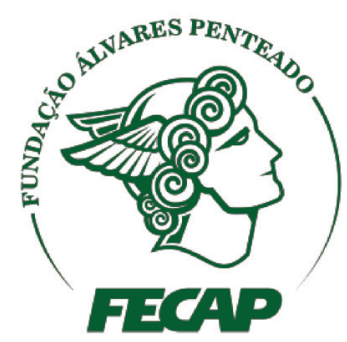

Revista Brasileira de Gestáo de Negócios

DOI: $10.7819 /$ rbgn.v22i2.4050 


\section{Introduction}

Accounting was born with the evolution of civilization, and its progress coincides with that of human beings (Sá, 1998). In the last decades, there have been significant changes in accounting and many countries have developed their own accounting standards based on the International Accounting Standards Board (IASB) or the Financial Accounting Standards Board (FASB) (Boolaky, 2006). The IASB and the FASB indicate that the qualitative characteristics of a conceptual framework are the attributes that make the information useful to users (Christensen, 2010). With its development, accounting has become an important source of financial information (FI), and with the progress of economic activity, it has come to be seen as an essential tool to support management (Schwartz, 2016). However, the "practitioner's views on the relationship between strategic management and financial accounting have endured changes over time, but no consensus on this issue has been reached so far" (Mihaylova \& Papazov, 2018, p. 24). Özturk and Özçelík (2014) maintain that the FI produced through accounting is thus a fundamental tool for the development of business activities, since it can assist the various FI users in decision making.

According to Akhtar and Liu (2018), financial statements (FSs) contain important information for making financial decisions. Hence, information available for internal purposes can be highly relevant for external FS users as well (Eierle \& Schultze, 2013). There are several types of FI, and each stakeholder assigns them different levels of usefulness. According to Macve (2010), there are two distinct functions of FSs, namely providing useful information for investment decisions and providing control information for monitoring and rewarding managers. Eierle and Schultze (2013, p. 158) argue that "in the absence of agency conflicts, accounting largely serves the information needs of managerial owners" and from this perspective it is possible to identify two central qualitative characteristics that make accounting information useful, namely predictive ability and feedback value. The authors also point out that the usefulness of FI in this configuration is broadly derived from the feedback value of information and performance measured on an ongoing basis, with the objective of providing timely information for management as a basis for corrective action.

For Auken, Aşcıgil and Carraher (2014), FSs, which are a structured representation of an entity's financial position, performance and changes in financial position, provide important information for assessing the impacts of various factors on previous or future decisions, such as liquidity, financing needs, and risk factors. The FI's utility has a positive relationship with the company's performance and survival (Amoako, 2013), and today, to overcome economic instability, it is necessary to analyse past FI to predict future risks (Mom, Fourné \& Jansen, 2015). This leads to the conclusion that FI-based management can determine a company's success (Amoako, 2013).

Given the above and the importance of FI in companies' performance, the objective of this study is to determine whether a manager's individual characteristics (gender, company owner, academic qualifications and management skills) and the characteristics of the company in which the manager works (size, applicable accounting standards, performance and seniority) have an impact on the usefulness of the FI. For this analysis, it is possible to develop and evaluate a theoretical model that allows this investigation to achieve its objectives.

This paper is structured as follows. In the next section, we address the conceptual background of the study that allowed us to develop the proposed research model and hypotheses. Next, we present the methodology and empirical study. The final section covers the discussion and conclusions, which include the limitations of the study and directions for future research. 


\section{Literature Review and Hypotheses Development}

According to Cvetkoska (2016, p. 350), organizational managers are decision makers and "making the right decision leads to the organization's success, whereas wrong decisions lead to failure, and in the worst case, to disintegration of the organization".

Decision making is a logical thought process conducted in an organizational environment by a person with legitimate decisionmaking power, who, with the help of specialized parties, seeks to prepare, manage, implement and control a given decision (Gencia, Sandu, Puscas \& Mates, 2016). It is not always easy to control this, because making decisions quickly can be dangerous and delaying for too long can mean lost opportunities (Saaty, 1996). To make a good decision, it is necessary to respect the decision process, which involves the recognition and evaluation of problems, strategy selection, information processing, strategy implementation and finally decision making (Akdere, 2011). In the decision-making process, according to Culp (2016), there must be more than one option, enabling the manager to choose between several alternatives. However, before making the decision, the manager must anticipate the possible outcomes and analyse the extent to which they achieve the desired goal. In fact, Akhtar and Liu (2018, p. 390) indicate that the benefits of using FSs in decision making are obvious and that FSs "should be utilized by the outside evaluators and inside firm, to guide better decisions". In this context, Florin (2014) indicates that accounting is an indispensable tool in the management of an entity and is decisive in the decision-making process.

With the evolution of society, accounting has become a useful tool in decision making but this has not always been the case. For a long time, the market and companies only used accounting to fulfil tax obligations and did not take advantage of its utility (Filzen \& Peterson, 2015). Currently,
FI is useful for different stakeholders (current and potential investors, employees, lenders, suppliers, customers and the state). They use FI to meet some of their different information needs (Gencia et al., 2016), which is largely due to the changes made by the IASB and the FASB in the last few decades.

In the accounting literature, there are several theories. The best known are agency theory, positive accounting theory, and decisionusefulness theory. Matsumura and Shin (2005, p. 102) state that according to agency theory, "managers (executives) who are not also owners are shareholders' agents and will not necessarily act in shareholders' best interests" and that they "are assumed to choose actions to maximize their own expected utility". Watts and Zimmerman (1978) indicate that it is important to keep in mind the motivations of managers because they contribute to the determination of accounting standards. These authors point out that "a precondition of a positive theory of standard-setting is understanding management's incentives" (Watts \& Zimmerman, 1978, 113). However, for Eierle and Schultze (2013), the incentive effect of FI and its implications for information that is useful for economic decision making by external investors has not yet been given special consideration by accounting standard setters. The decisionusefulness theory is related with accounting standards that provide useful FI to users in their decision processes (Dandago \& Hassan, 2013). Although decision-usefulness has been adopted by the IASB and the FASB, which have defined qualitative characteristics that make information useful to the various users (Christensen, 2010), they have been subject to criticism. In this context, Eierle and Schultz (2013) point out that there are qualitative characteristics that overlap, which makes it difficult to identify the economic phenomenon that is most relevant for decision making and that can simultaneously be represented in a trustworthy way.

According to Gencia et al. (2016), FI is the basic source of intelligence that affects 
the behaviour of users (internal and external) when dealing with an economic entity, and it is provided through a reporting system in which the descriptive value influences the decision maker regarding a particular action.

Bondt and Thaler (1995) maintain that FI is valued by managers and is fundamental to the decision-making process. In addition, Amoako (2013) emphasizes that FI analysis allows managers to obtain accurate information on which to base their decisions. Frydman and Camerer (2016) argue that financial decisions are the most important ones that an organization will make. The same authors point out that, in these decisions, FI is necessary for managers to be able to determine profits or losses and assets and liabilities (among others) at any given moment. Amoako (2013) states that the utility of the FI (attributed by the manager) thus has a positive relationship with the performance and survival of the company. Moreover, according to the same author, a lack of accounting records can lead to the closure of some companies and therefore poses a significant problem for business success.

For good decision making, a manager needs complete, adequate and up-to-date FI, which in most companies is not available, making decision making risky (Culp, 2016). The majority of Small and Medium-sized Enterprises (SMEs) do not survive beyond the first few months of existence, which is partly due to the lack of FI and sound management of their financial situation (Amoako, 2013).

Mukhametzyanov and Nugaev (2016) state that the main objective of using FI is to reduce uncertainty in decision making and that economic analysis and reliable decision making are only possible if there is useful information about the company's activity. Managers tend to use different kind of FSs, but the question is how the managers of companies use FSs in economic decision making (Macve, 2010). FS analysis represents an intermediate step between the FI and the stakeholder's final decision (Gencia et al., 2016). In this way, accounting and management are intrinsically linked to good business conduct, which is only possible if the manager analyses the FI produced by certified accountants (CAs) efficiently (Montesinhos, 1993).

Despite the importance given to FI, according to Amoako (2013), there is currently a shortage of studies that analyse the usefulness of FI in decision making. This author indicates that the few studies focus only on Micro, Small and Medium Enterprises (MSMEs) and that the results show that most businesses are inefficiently managed and, in turn, managers have poor business-sustaining skills, a condition that sometimes leads to loss of control in day-to-day operational situations, placing the company in a risky economic situation.

MSMEs represented $99.9 \%$ of Portugal's business fabric in 2016, employing about four out of five workers (79\%). They are very important for the Portuguese economy. Studies indicate that the role of the manager differs according to the size of the company (Frydman \& Camerer, 2016; İbicioglu, Kocabiyik \& Dalgar, 2010). In small companies, managers are spokespersons, because, in their daily life, they spend a great deal of time on actions that are carried out externally, namely in meetings with clients, in financing negotiations, in identifying new opportunities and in stimulating change in the organization; while managers of large companies occupy their time deciding which organizational units need resources and how to obtain them (İbicioglu et al., 2010).

Thus, according to agency theory, large companies come across a separation of functions and divergence of interests between the owner(s)/ shareholder(s) and manager(s) (or the board of directors). In these companies, only a small group makes financial decisions, usually the Chief Executive Officer (CEO) and other directors, overseen by the board of directors (Frydman \& Camerer, 2016).

İbicioglu et al. (2010) report that, when compared with large firms, small firms have less liquidity, have more volatile cash flows, rely on short-term financing and are more likely to 
experience financial difficulties and constraints. These authors further state that the failure rates in small businesses are unacceptably high. The cause of this, according to Amoako (2013), may be related to the fact that managers of micro-companies assign less importance to FI in decision making. Based on the agency and decision-usefulness theories, the first hypothesis of this investigation is defined:

\section{$\mathbf{H}_{\mathbf{1}}$ - Managers of larger companies attach greater usefulness to FI in decision making.}

In Portugal, the Accounting Standardization System provides for the recognition, measurement, disclosure and particular aspects of the presentation of specific transactions and other events, depending on company size, and according to the Accounting and Financial Reporting Standards (general regime), the Accounting and Financial Reporting Standards for small companies, and the Accounting Standards for micro-companies (Decree-Law no. 198/2015 of 2 June, amending Decree-Law no. 158/2009 of 13 July). However, listed companies present their FI in accordance with the International Accounting Standards based on Regulation of the European Parliament no. 1606/2002 and of the Council of 19 July. According to these regulations, larger companies are the ones that present the most complete FI, i.e., there is a relationship between the size of the company and the extent of the FI.

According to the decision-usefulness theory, the objective of accounting is to provide information for use in the decision making process (Staubus, 2000). In larger firms, FSs are more complete, given the applicable norms, in which case there is a greater propensity to meet or exceed managers' expectations regarding the FI's utility (Filzen \& Peterson, 2015). Thus, managers of larger companies attach greater importance than SME managers to FSs as a tool to support economic decision making (Özturk \& Özçelík, 2014). Therefore, this study's second hypothesis is formulated:

\section{$\mathrm{H}_{2}-$ Managers of companies that elaborate more complete FSs assign more usefulness to FI in decision making.}

Rapid changes in technology and the level of globalization have caused important changes in the economic scenario, leading to a rethink about how companies are being managed and what lies behind their success (Zehir \& Özasahin, 2008). The model of the strategic decision-making process proposed by Wheelen and Hunger (2004) identifies eight steps in a strategy decision-making process, the first being related to the company's current performance. According to Macve (2010), FSs are a performance indicator that allows managers to make decisions, besides enabling them to establish comparisons with the past and detect deviations between actual and estimated performance, thus facilitating projections for the future.

Agency theory suggests the need to establish accounting standards that allow, based on performance measures, managers' incentives to be accurately defined so they act according to the company owner's/owners' interests (Eierle $\&$ Schultze, 2013). Positive accounting theory supposes that when managers have different accounting options, they tend to make decisions in order to obtain the desired result. On the other hand, according to decision-usefulness theory, the utility attributed to FI by the manager has a positive relationship with the company's performance and survival (Amoako, 2013). Thus, for Macve (2010), managers of companies with better performance attribute greater relevance to FI in decision making. In the context of these three theories, we formulate the third hypothesis:

\section{$\mathbf{H}_{3}-$ Managers of companies with better performance attribute more usefulness to FI in decision making.}

Sorensen and Stuart (2000) argued that the company's age affects its performance and that organizational inertia in older firms tends to 
make them inflexible and unable to appreciate changes in the environment, which affects decision making and consequently the results of the company.

On the other hand, Liargovas and Skandalis (2010) reported that older firms are more skilled since they have enjoyed the benefits of learning and are not prone to the liabilities of newness; hence, they have superior performance.

Mihăilăa (2014) asserts that accounting plays a prominent role in the decision-making process because it supports business management in the planning, decision making, control, analysis and effective use of all FI produced by accountants. According to Florin (2014), this FI increases gradually as the entity develops its activity. Thus, based on the accounting data collected throughout a company's operations, the manager can make decisions related to productive, commercial and financial activities. Following the decision-usefulness theory framework, we propose the fourth hypothesis of this investigation:

\section{$\mathbf{H}_{4}$-Managers of older companies attribute more usefulness to FI in decision making.}

For Fujianti (2018), the success or failure of a company in achieving its goals highly depends on the manager. This author indicates that personal characteristics of managers include gender, age, education, experience and tenure. The literature suggests that, in addition to the contextual factors, the manager's individual characteristics influence the usefulness that he or she attributes to the FI (Amoako, 2013). However, in the literature there is a scarcity of studies that, following the decision-usefulness theory framework, analyse the relationship between the manager's individual characteristics and the usefulness of FI.

According to Manning and Robertson (2010), male and female managers tend to be judged by different gender stereotypes and carry out different jobs. Each manager, regardless of gender, is unique; however, women tend to be disadvantaged. Financed by capital, organisations around the world exploit the labour of the world's poorest and least educated women, often in sweatshop conditions (Haynes, 2008). These less satisfactory results are related to differences in personality traits that exist between male and female managers (Carland \& Carland, 1991). In this context, we formulate the fifth hypothesis:

\section{$\mathbf{H}_{5}-$ Male managers attribute greater usefulness to FI in decision making.}

According to Glancey (1998), in small companies, ownership and control of capital are usually in the hands of the key decision maker, who plays a strong role in how the firm pursues its objectives; while in large companies there is a separation of ownership and control, with managers or administrators being responsible for making decisions on the main functions of the company.

The study by Hendry, Sanderson, Barker and Roberts (2006) shows that responsible managers are quite different from managers who are also owners of the company. Most of the companies analysed in the study by Amoako (2013) are run by the owner or a close relative, and usually in these cases the manager does not use FI in decision making, which can condition business success. The fact that a company is managed by the owner or a close relative may reduce the usefulness of the FI, since there are few managers who ask accountants to go beyond obligations for tax purposes, thus assigning little utility to FI (Hendry et al., 2006). In view of the above, we formulate the sixth hypothesis:

\section{$\mathbf{H}_{\mathbf{6}}-$ Managers who are not owners of the company attribute more usefulness to FI in decision making.}

Knowledge has been classified into two types: explicit and tacit knowledge (Anand, Clickand, \& Manz, 2002; Nonaka, 1991). Explicit knowledge is acquired through education/ training and tacit knowledge is acquired through 
experience (Anand et al., 2002). According to Abubakar, Elrehail Alatailat and Elçi (2018), the level of manager training (explicit knowledge) has an influence on decision making; managers who have more knowledge make more prudent decisions. However, Amoako (2013) argues that academic qualifications are a critical element used in understanding the behaviour of entrepreneurs and managers and, in most cases, are what determines the success of the manager. Therefore, the same authors maintain that for the manager to make the best decisions, they must understand the dynamics and changes posed by business management, which implies having qualifications in higher education. In view of the above, we define the seventh hypothesis:

$\mathbf{H}_{7}$ - Managers with academic qualifications at the higher education level attribute more usefulness to FI in decision making.

Abubakar et al. (2018) asserts that managerial skills are a blend of contextual information, framed experience, expert experience and value that result in innovation and pristine experience. Furthermore, according to the same authors, tacit knowledge is influenced by organizational culture, skills, reputation, intuition and codified theory that influences human behaviour and thought. On the other hand, Tang and Liu (2016) argue that managers with higher skills levels are more assertive and risk prone when making decisions than managers with less knowledge and experience. According to Amoako (2013), most managers have limited knowledge in management, namely in accounting and finance, presenting difficulties in the interpretation and analysis of FI. In view of the above, we formulate the eighth hypothesis:

\section{$\mathbf{H}_{\mathbf{8}}$ - Managers with managerial skills assign greater usefulness to FI in decision making.}

The hypotheses defined above are evident in the operational model that we propose for this research, which is presented below (figure 1).

\section{Model and Methodology of the Study}

\section{I Operational model}

To evaluate the factors influencing the utility of FI in decision making, an operational model is developed that relates the individual characteristics of the manager and the characteristics of the company in which the manager performs their role with the FI's usefulness in decision making (figure 1).

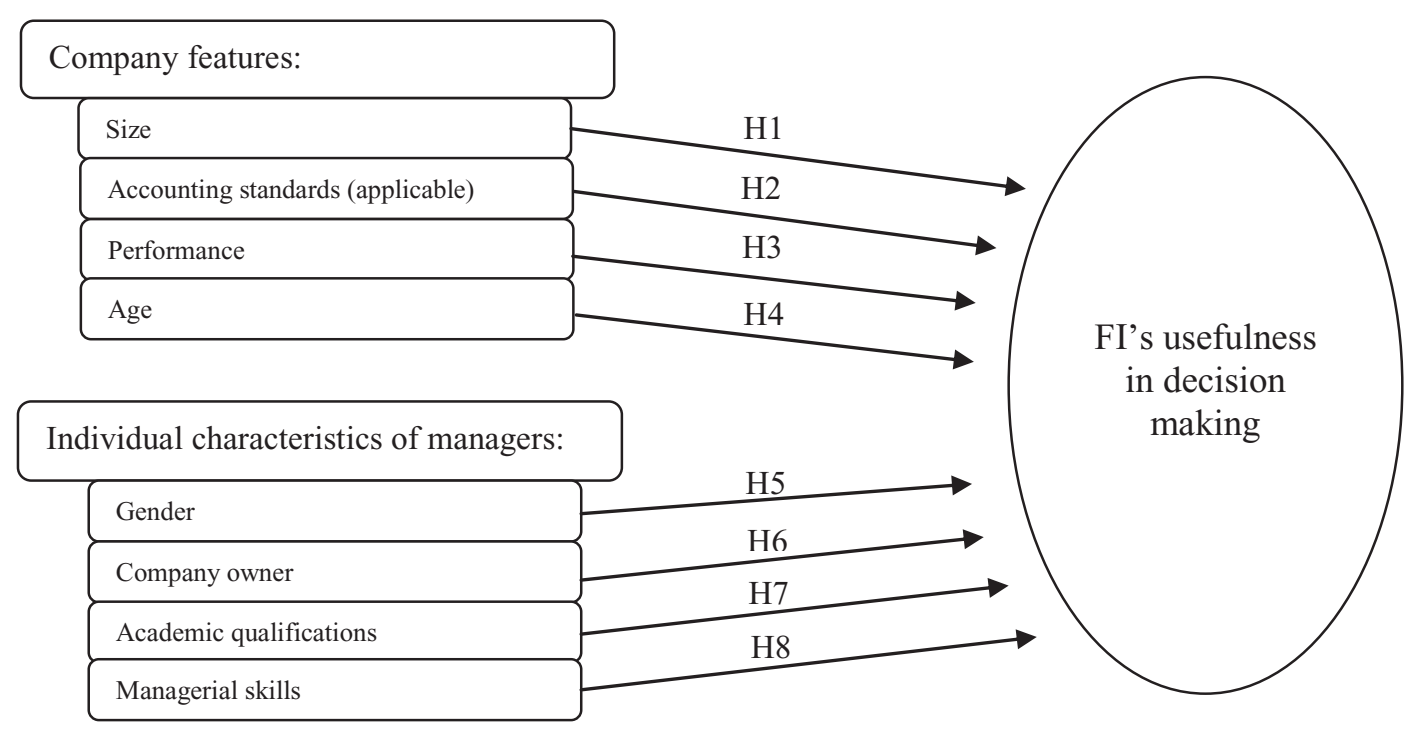

Figure 1. Operational model. 
This research continues the studies by İbicioglu et al. (2010); however, it covers new variables related to the characteristics of the company and its manager, as well as companies of all dimensions that belong to the Portuguese business fabric.

\subsection{Methodology}

To achieve the proposed objective, the operationalization of this research is based on a quantitative survey applied to CAs registered with the Order of Certified Accountants (OCC). This survey is directed at CAs because they are the ones who prepare companies' FI and are able to evaluate its usefulness depending on the type of information that is normally produced and what is actually requested by the manager.

Note that in Portugal, CAs practicing the profession must be registered with the OCC. In this study, the application of the survey to CAs relied on the collaboration of the OCC, which agreed to publish the survey on its institutional website. In this way, it was possible to collect responses quickly, without any cost and in great quantity, and to guarantee the confidentiality of the data (Gillham, 2000).

In this investigation, we test the hypotheses formulated in the proposed operational model, resorting initially to non-parametric tests, using a level of significance of 0.05 . The tests performed in the study are the Kruskal-Wallis, Mann-Whitney and Spearman's ordinal correlation tests. Through them, it is possible to verify that the hypotheses regarding the relationships between the variables (Bell, 2005).

\subsection{Measuring instrument}

In this study, we developed a survey. To test the survey, a pre-test was carried out on 11 people, who included accounting professionals and higher education teachers. The result of the pre-test led to changes, reformulations and the organization of some questions.

The final version of the survey includes questions related to the profile of the respondents intended to obtain information about the certified accountants (gender, age, educational qualifications and work experience), questions that aim to portray the profile of the company in which the manager performs their functions (size, applicable standards, age and performance), questions about the manager (gender, business owner, academic qualifications and managerial skills) chosen to respond to this study, as well as questions that allow us to evaluate the usefulness of FI in decision making.

To measure the usefulness of the FI and company performance, we use the items presented in table 1 , which are based on several authors. These items are evaluated on a five-point Likert scale in which 1 corresponds to strongly disagree and 5 corresponds to totally agree.

Table 1

\section{Usefulness of FI}

\begin{tabular}{ll}
\hline Usefulness of FI & Author(s) \\
\hline The manager of the company requests another type of FI beyond that of the FSs. & Amoako (2013) \\
The manager of the company attaches great value to FI. & Bondt and Thaler (1995) \\
$\begin{array}{l}\text { The company manager gives due importance to financial indicators in the } \\
\text { decision-making process. }\end{array}$ & Jaffar, Selamat, Ismail and Hamzah \\
\hline
\end{tabular}

To measure company performance, we use the items shown in table 2 , utilizing the five-point Likert scale presented above. 
Table 2

\section{Company performance}

\begin{tabular}{l}
\hline Company performance \\
\hline Turnover has increased over the last 3 years. \\
The business has been very lucrative. \\
The company has expanded its activity in the last 3 years. \\
The company has increased its market share in the last 3 years. \\
The size of the company has increased in the last 3 years. \\
The number of employees has increased in the last 3 years. \\
\hline
\end{tabular}

\subsection{Data and sample characteristics}

In the data collection process, which occurred from 31 May 2017 to 5 July 2017, 200 responses were obtained, equivalent to $0.28 \%$ of the population size $(70,728 \mathrm{CAs})$. As the study evaluates the perception of CAs, 43 responses are eliminated because the respondents do not currently practice this profession, resulting in 157 responses. As such, it is a convenience sample and not a probabilistic sample.

To ensure an adequate analysis of the data collected in the survey, we use the statistical software IBM SPSS, version 22.

Of the 157 CAs surveyed, the majority are male $(52.87 \%)$ and $47.13 \%$ are female. Most of the CAs interviewed are aged 41 or over (68.15\%), with the remainder (31.85\%) being of a lower age. Regarding educational qualifications, $65.61 \%$ of the CAs have a bachelor's degree and $20.38 \%$ have a master's degree, with only $12.10 \%$ of the sample having only secondary education and $1.91 \%$ only up to the ninth grade. No respondent has a $\mathrm{PhD}$.

In this study, it was possible to verify that $100(63.68 \%)$ of the 157 CAs work in more than 1 company and only 57 (36.31\%) work in only 1 company. The results show that 18 (11.46\%) of the CAs interviewed have experience of up to 5 years; 18 (11.46\%) have between 6 and 10 years; 23 (14.66\%) have between 11 and 15 years; and 29 (18.47\%) have between 16 and 20 years. Furthermore, $74.08 \%$ of the respondents have been working for more than 10 years.

\section{Results}

Given the objectives of the study, we evaluated the factors that influence the utility of FI, as attributed by the manager, in decision making. These factors relate to the company and the characteristics of the manager.

\section{I Hypothesis testing}

Regarding the relationship between firm size and usefulness of FI, as we can see in table 3 , the results reject $\mathrm{HO}$ at the significance level of 0.05 , since the p-value $<0.05$. By means of an analysis of the mean positions, it can be concluded that it is large companies that attribute the most utility to FI (mean position $=121.33$ ), with micro-entities considering it to be less useful (mean position $=68.47$ ). In view of the above, in this study it is concluded that the larger the company size, the greater the utility attributed to FI by the company's manager, thus supporting $\mathrm{H} 1$. These results are in line with the findings of Özturk and Özçelík (2014). 
Table 3

Kruskal-Wallis test for hypothesis 1

\begin{tabular}{|c|c|c|c|}
\hline \multicolumn{4}{|c|}{ Classification } \\
\hline Type of en & & $\mathbf{N}$ & Position average \\
\hline Usefulness & Micro-company & 90 & 68.47 \\
\hline of FI & Small company & 41 & 89.33 \\
\hline & Medium and large companies & 26 & 121.33 \\
\hline & Total & 157 & \\
\hline \multicolumn{4}{|c|}{ Test statistics ${ }^{\mathrm{a}, \mathrm{b}}$} \\
\hline \multicolumn{4}{|c|}{ Usefulness of FI } \\
\hline Chi-square & & \multicolumn{2}{|r|}{14.079} \\
\hline Df & & \multicolumn{2}{|r|}{3} \\
\hline Significanc & & \multicolumn{2}{|r|}{.003} \\
\hline
\end{tabular}

a. Kruskal-Wallis test

b. Grouping variable: type of entity

The relationship between the accounting standard applicable to the companies and the usefulness of the FI is tested, and the results show a significance level of 0.05 for the Kruskal-Wallis test, thus rejecting $\mathrm{H} 0$, since the $\mathrm{p}$-value $<0.05$ (table 4). From analysing the average positions, it is concluded that the companies with more complete SFs attribute greater usefulness to FI $($ mean position $=121.33)$. Accordingly, we conclude that the results are coincident with the findings of Filzen and Peterson (2015).

Table 4

\section{Kruskal-Wallis test for hypothesis 2}

\begin{tabular}{|c|c|c|c|}
\hline \multicolumn{4}{|c|}{ Classification } \\
\hline \multicolumn{2}{|c|}{ Accounting standards } & $\mathbf{N}$ & Position average \\
\hline Usefulness & Accounting standards: general regime & 51 & 75.42 \\
\hline of FI & Accounting standards: small company & 41 & 87.17 \\
\hline & Accounting standards: micro-company & 59 & 72.11 \\
\hline & International accounting standards & 6 & 121.33 \\
\hline & Total & 157 & \\
\hline \multicolumn{4}{|c|}{ Test statistics ${ }^{\mathrm{a}, \mathrm{b}}$} \\
\hline \multicolumn{4}{|c|}{ Usefulness of FI } \\
\hline \multicolumn{2}{|c|}{ Qui-quadrado } & \multicolumn{2}{|r|}{8.298} \\
\hline \multicolumn{2}{|c|}{ Df } & \multicolumn{2}{|r|}{3} \\
\hline \multicolumn{2}{|l|}{ Significance } & \multicolumn{2}{|r|}{.040} \\
\hline
\end{tabular}

a. Kruskal-Wallis test

b. Grouping variable: accounting standards

In regards to the relationship between the company's performance and the usefulness of FI, the Spearman test, at the significance level of 0.05 , rejects $\mathrm{H0}$, since the p-value $<0.05$ (table 5). The results show a weak $(R=33.7)$ but significant and positive correlation, which leads us to conclude that managers with higher performance attribute more usefulness to FI. The results are in agreement with the findings of Macve (2010). 
Table 5

Spearman correlations for hypothesis 3

\begin{tabular}{llcc}
\hline & & Correlations & \\
\hline & & Usefulness of FI & Company performance \\
\hline Usefulness of FI & Pearson correlation & 1 & $.337^{* *}$ \\
& Sig. (2 ends) & & .000 \\
& $\mathrm{~N}$ & 157 & 157 \\
\hline Company performance & Pearson correlation & $.337^{* *}$ & 1 \\
& Sig. (2 ends) & .000 & 157 \\
\hline
\end{tabular}

** The correlation is significant at the 0.01 level (2 extremities).

The Spearman's correlation test of the relationship between older firms and the usefulness of FI suggests that, at the significance level of $0.05, \mathrm{H} 0$ can be rejected, since the p-value $<0.05$ (table 6). The results show a weak
$(\mathrm{R}=21.5)$ but significant and positive correlation, leading to the conclusion that older managers attribute more usefulness to FI. Therefore, we conclude that the results oppose Florin's (2014) findings.

Table 6

\section{Spearman correlations for hypothesis 4}

\begin{tabular}{llcc}
\hline & Correlations & & \\
\hline & & Age & Usefulness of FI \\
\hline \multirow{2}{*}{ Age } & Pearson correlation & 1 & $.215^{* *}$ \\
& Sig. (2 ends) & & .007 \\
& $\mathrm{~N}$ & 157 & 157 \\
\hline Usefulness of FI & Pearson correlation & $.215^{* *}$ & 1 \\
& Sig. (2 ends) & .007 & 157 \\
& $\mathrm{~N}$ & 157 & \\
\hline
\end{tabular}

** The correlation is significant at the 0.01 level (2 extremities).

The gender of the manager does not have a significant impact on the usefulness that he or she assigns to FI. The results of the Mann-Whitney test show that, based on the mean position, female managers attribute greater utility to FI, but this result is not significant, since the p-value $>0.05$, and so $\mathrm{H} 0$ is not immediately rejected (table 7). The results of this investigation contradict the findings of Haynes (2008). 
Table 7

Mann-Whitney test for hypothesis 5

\begin{tabular}{|c|c|c|c|c|}
\hline \multicolumn{5}{|c|}{ Classification } \\
\hline \multicolumn{2}{|c|}{ Gender of the company manager } & $\mathbf{N}$ & Mean position & Sum of ratings \\
\hline Usefulness & Female & 31 & 83.52 & 2589.00 \\
\hline of FI & Male & 126 & 77.89 & 9814.00 \\
\hline & Total & 157 & & \\
\hline \multicolumn{5}{|c|}{ Test statistics ${ }^{\mathrm{a}}$} \\
\hline \multicolumn{5}{|c|}{ Usefulness of FI } \\
\hline \multirow{3}{*}{\multicolumn{2}{|c|}{$\begin{array}{l}\text { U Mann-Whitney } \\
\text { Wilcoxon W } \\
\text { Z }\end{array}$}} & \multicolumn{3}{|c|}{1813.000} \\
\hline & & \multicolumn{3}{|c|}{9814.000} \\
\hline & & \multicolumn{3}{|c|}{-.621} \\
\hline \multicolumn{2}{|c|}{ Significance ( 2 ends) } & \multicolumn{3}{|c|}{.535} \\
\hline
\end{tabular}

a. Grouping variable: gender of the company manager

As can be seen from the Mann-Whitney test, it is possible to conclude that a manager who is not the owner of the company assigns more utility to FI (mean position $=96.64$ ). At the significance level of 0.05 , we reject Ho because the p-value $<0.05$; that is, when he or she does not own the company, the manager assigns greater importance to FI in decision making. The results are consistent with the findings of Hendry et al. (2006).

Table 8

\section{Mann-Whitney test for hypothesis 6}

\begin{tabular}{|c|c|c|c|c|}
\hline \multicolumn{5}{|c|}{ Classification } \\
\hline Company & & $\mathbf{N}$ & Mean position & Sum of ratings \\
\hline Usefulness & No & 22 & 96.64 & 2126.00 \\
\hline of FI & Yes & 135 & 76.13 & 10277.00 \\
\hline & Total & 157 & & \\
\hline \multicolumn{5}{|c|}{ Test statistics ${ }^{\mathrm{a}}$} \\
\hline \multicolumn{5}{|c|}{ Usefulness of FI } \\
\hline \multicolumn{2}{|c|}{ U Mann-Whitney } & \multicolumn{3}{|c|}{1097.000} \\
\hline \multicolumn{2}{|c|}{ Wilcoxon W } & \multicolumn{3}{|c|}{10277.000} \\
\hline \multicolumn{2}{|c|}{$\mathrm{Z}$} & \multicolumn{3}{|c|}{-1.974} \\
\hline \multicolumn{2}{|c|}{ Significance (2 ends) } & \multicolumn{3}{|c|}{.048} \\
\hline
\end{tabular}

a. Grouping variable: company owner

The literature suggests that managers who are trained at a higher level attribute greater utility to FI (Amoako, 2013). The results of this study support this assertion, since the MannWhitney test (mean position $=95.35$ ) supports hypothesis 7 , as, at the significance level of 0.05 , it rejects $\mathrm{H} 0$ with a p-value $<0.05$ (table 9). The results of this study are in line with Amoako's (2013) findings, indicating that a manager's lack of academic training makes it difficult for him or her to interpret FI, causing less utility to be attributed to it. 
Table 9

Mann-Whitney test for hypothesis 7

\begin{tabular}{|c|c|c|c|c|}
\hline \multicolumn{5}{|c|}{ Classification } \\
\hline Higher educ & & $\mathbf{N}$ & Mean position & Sum of ratings \\
\hline Usefulness & No & 71 & 59.20 & 4203.00 \\
\hline of FI & Yes & 86 & 95.35 & 8200.00 \\
\hline & Total & 157 & & \\
\hline \multicolumn{5}{|c|}{ Test statistics ${ }^{a}$} \\
\hline \multicolumn{5}{|c|}{ Usefulness of FI } \\
\hline \multirow{3}{*}{\multicolumn{2}{|c|}{$\begin{array}{l}\text { U Mann-Whitney } \\
\text { Wilcoxon W } \\
\text { Z }\end{array}$}} & \multicolumn{3}{|c|}{1647.000} \\
\hline & & \multicolumn{3}{|c|}{4203.000} \\
\hline & & \multicolumn{3}{|c|}{-4.989} \\
\hline \multicolumn{2}{|c|}{ Significance (2 ends) } & \multicolumn{3}{|c|}{.000} \\
\hline
\end{tabular}

a. Grouping variable: higher education

Finally, as for the relationship between knowledge in the area of management and the utility attributed to FI by the manager, at the significance level of 0.05 , the Kruskal-Wallis test rejects $\mathrm{H} 0$, because the $\mathrm{p}$-value $<0.05$ (mean po- sition $=118.81$, thus attributing decision making to FI (table 10). The results of this study are in line with Amoako's (2013) findings, which indicate that a manager with less knowledge in the management area attributes less utility to FI.

Table 10

Kruskal-Wallis test for hypothesis 8

\begin{tabular}{|c|c|c|c|}
\hline \multicolumn{4}{|c|}{ Classification } \\
\hline \multicolumn{2}{|c|}{ Management knowledge } & $\mathbf{N}$ & Mean position \\
\hline Usefulness & Totally agree & 6 & 15.33 \\
\hline of FI & Partially agree & 29 & 37.24 \\
\hline & Indifferent & 36 & 69.46 \\
\hline & Partially disagree & 44 & 85.01 \\
\hline & Strongly disagree & 42 & 118.81 \\
\hline & Total & 157 & \\
\hline \multicolumn{4}{|c|}{ Test statistics ${ }^{\mathrm{a}, \mathrm{b}}$} \\
\hline \multicolumn{4}{|c|}{ Usefulness of FI } \\
\hline Chi-square & & & 71.659 \\
\hline Df & & & 4 \\
\hline Significance & & & .000 \\
\hline
\end{tabular}

a. Kruskal-Wallis test

b. Grouping variable: management knowledge

In view of the above, it is possible to conclude that only one hypothesis is not supported by the conceptual model (H5). 


\section{Conclusion, Limitations and Directions for Future Research}

\section{I Conclusion}

According to Cvetkoska (2016, p. 350), "making decisions under various forms of pressure, such as strong competition, increasingly demanding clients who seek lower prices, rapid technological changes, limited resources and time constraints, is not easily resolved". In this context, Smith (2017, p. 429) states that "business has changed in a wide variety of ways, and one of the most prominent is the increasing use of analytics in the business decision making process". Accounting has followed these changes and has become an important source of information, since it can help managers to make decisions and influence businesses' performance.

Currently, in Portugal, there is a high rate of bankruptcies and dissolutions, mostly in SMEs and micro-entities. This is a concern for the economy and is generally blamed on inefficient management. For good decision making, it is necessary to use and analyse FI, prepared and disclosed by accountants, to assess past mistakes and predict future risks. Given the importance that FI assumes for decision making, it is the objective of this study to evaluate the factors that influence the utility of FI, as attributed by managers, in decision making. These factors relate to the company and the characteristics of the manager.

The results of this study, based on a survey conducted among CAs, reveal that there are contextual and individual factors of managers that influence the importance that they attribute to FI. Regarding the contextual factors, those that influence the utility attributed by managers to FI are size, performance and age as well as the applicable accounting regulations. We can thus conclude the following: (1) the size of the company influences the usefulness of FI, because, on one hand, in a larger company more demanding controls and greater rigour in the decision-making process are necessary, and on the other hand, following the agency and decision-usefulness theories framework, the managers of these companies tend, for financial incentive reasons, to attribute importance to FI in their decisions in order to achieve the desired performance results; (2) the managers of companies with better performance attribute more utility to FI in decision making, because they can be compensated in accordance with the performance of the company (agency and positive accounting theories), and to obtain good performance, managers need to use FI to make the best decisions, as suggested by Özturk and Özçelík (2014) and as according to decision-usefulness theory; (3) managers of older companies also attribute more usefulness to FI in decision making, since by resorting to historical data, companies can provide more information (past and present) to managers and influence their decisions (Filzen \& Peterson, 2015), as predicted by decision-usefulness theory.

The individual characteristics of managers that influence the usefulness that they attribute to FI are academic qualifications at the higher education level and non-owner managers with management skills. These results are consistent with the literature (decision-usefulness theory). Conversely, the gender of the manager does not statistically influence the usefulness of FI.

Based on the literature review, a gap was identified in terms of the scarcity of studies that address the subject in this context and in Portugal. For the success of a company, the FI prepared by a CA is an indispensable and useful management tool for all the stakeholders in decision making. In this context, this research is relevant to the development of the literature and to practice. This study identifies the characteristics of individual managers and of the context that have a significant impact on FI's usefulness in decision making, which can help CAs to understand what kind of information is valued and should be prepared for the manager. On the other hand, this study proves to be important for managers in the 
sense that they can identify the characteristics that should be developed to enable better use of FI in decision making and consequently better company performance. According to Amoako (2013), good management determines the success and survival of a company, which is only possible if the manager in question analyses FI to predict future results and improve the company's current activity.

\subsection{Limitations and directions for future research}

This study, like all studies, has some limitations, particularly in terms of the size of the survey sample, since we use a convenience sample, which limits the generalizability of the results. Another limitation is the fact that the survey is not applied directly to managers, although we understand that accountants have enough knowledge regarding the utility that managers assign to the FI they request.

In terms of future research, we recommend considering additional forms of survey with the OCC's support. Additionally, we propose the application of this study directly to managers to compare the results obtained. We also suggest an analysis of the impact of the factors and utility of FI on corporate performance using the structural equations model.

\section{References}

Abubakar, A., Elrehail. H., Alatailat. M., \& Elçi, A. (2017). Knowledge management, decisionmaking style and organizational performance, Journal of Innovation \& Knowledge, 2(3), 97-182.

Akdere, M. (2011). An analysis of decisionmaking process in organizations: Implications for quality management and systematic practice. Total Quality Management, 22(12), 1317-1330.

Akhtar, S., \& Liu, Y. (2018). SMEs' use of financial statements for decision making: Evidence from Pakistan. Journal of Applied Business Research, 34(2), 381-392.
Amoako, G. K. (2013). Accounting practices of SMEs: A case study of Kumasi Metropolis in Ghana. International Journal of Business and Management, 8(24), 73-83.

Anand, V. Click, W. H., \& Manz, C. C. (2002). Thriving on the knowledge of outsiders: tapping organizational social capital. Academy of Management Executive, 16(1), 87-101.

Auken, H., van, Aşcigil, S., \& Carraher, S. (2014, July). The use of financial statements by Turkish SMEs. [Paper presented at Cambridge Business and Economics Conference]. Cambridge, United Kingdom.

Bell, J. (2005). Doingyour research project: A guide for first-time researchers in education, health and social science. England: Open University Press.

Boolaky, P. K. (2006). Measuring de jure harmonisation: A content analysis of the accounting standards of three countries: South Africa, Mauritius and Tanzanian and International Financial Reporting Standards. Journal of Applied Accounting Research, 8(2), 110-146.

Bondt, W., \& Thaler, R. (1995). Financial decision-making in markets and firms: A behavioral perspective. In R. A. Jarrow, V. Maksimovic, \& W.T. Ziemba (Eds.). Handbooks in Operations Research and Management Science (Vol. 9, Cap. 13, pp. 385-410). Amsterdã: Elsevier.

Carland, J., \& Carland, J. (1991). An empirical investigation into the distinctions between male and female entrepreneurs and managers. International Small Business Journal, 9(3), 62-72.

Christensen, J. (2010). Conceptual frameworks of accounting from an information perspective. Accounting and Business Research, 40(3), 287-299.

Culp, C. (2016). Judgment and decision making in outdoor adventure leadership: A dual-process model. Journal of Outdoor Recreation, Education, and Leadership, 8(1), 57-74. 
Cvetkoska, V. (2016). A survey of the use of operational research in decisions made by micro, small and medium-sized enterprises in Macedonia. Croatian Operational Research Review, $7(2), 349-365$.

Dandago, K. I., \& Hassan, N. I. B. (2013). Decision usefulness approach to financial reporting: a case for Malaysian revenue board? Asian Economic and Financial Review, 3(6), 772-784.

Decree-Law no. 198/2015 of 2 June.

Eierle, B., \& Schultze, W. (2013). The role of management as a user of accounting information: Implications for standard setting. Accounting and Management Information Systems, 12(2), 155-189.

Filzen, J., \& Peterson, K. (2015). Financial statement complexity and meeting analysts' expectations. Contemporary Accounting Research, 32(4), 1560-1594.

Florin, B. (2014). Development of decision making by managers with financial and accounting information. Economic Sciences, 23, 40-56.

Frydman, C., \& Camerer, C. (2016). The psychology and neuroscience of financial decision making. Trends in Cognitive Sciences, 20(9), 661-675.

Fujianti, L. (2018). Top management characteristics and company performance: An empirical analysis on public companies listed in the Indonesian stock exchange. European Research Studies Journal, 21(2), 62-76.

Gencia, A., Sandu, A., Puscas, A., \& Mates, D. (2016). An international perspective upon the impact of financial statement form on the business decision making process. Lucrari Stiintifice, 18(1), 109-116.

Gillham, B. (2000). Developing a questionnaire. London: Continuum.
Glancey, K. (1998). Determinants of growth and profitability in small entrepreneurial firms. International Journal of Entrepreneurial Behaviour \& Research, 4(4), 18-27.

Haynes, K. (2008). Moving the gender agenda or stirring chicken's entrails? Where next for feminist methodologies in accounting?. Accounting, Auditing \& Accountability Journal, 21(4), 539555.

Hendry, J., Sanderson, P., Barker, R., \& Roberts, J. (2006). Owners or traders? Conceptualizations of institutional investors and their relationship with corporate managers. Human Relations, 59(8), 1101-1132.

İbicioglu, H., Kocabiyik, T., \& Dalgar, H. (2010). Financial statement utilization during decision making process in SMEs: A comparative study on European and Turkish managers. Marmara Üniversitesi, 28(1), 209-226.

Jaffar, N., Selamat, Z., Ismail, N., \& Hamzah, H. (2012). 'The usefulness of the SMEs' accounting information. Journal of Modern Accounting and Auditing, 8(10), 1407-1418.

Liargovas, P., \& Skandalis, K. (2010). Factor affecting firm's financial performance: The Case of Greece Industry. European Industrial Journal, 2(2-3), 184-197.

Macve, R. (2010). Conceptual frameworks of accounting: Some brief reflections on theory and practice. Accounting and Business Research, 4O(3), 303-308.

Manning, T., \& Robertson, B. (2010). Seniority and gender differences in 360-degree assessments of influencing, leadership and team behaviours. Part 1: Introduction and seniority differences. Industrial and Commercial Training, 42(2), 139146.

Matsumura, E. M., \& Shin, J. Y. (2005). Corporate governance reform and $\mathrm{CEO}$ compensation: 
Intended and unintended consequences. Journal of Business Ethics, 62, 101-113.

Mihăilăa, M. (2014). Managerial accounting and decision making, in energy industry. Procedia Social and Behavioral Sciences, 109, 1199-1202.

Mihaylova, L., \& Papazov, E. (2018). Using accounting information for strategic decisionmaking in a multi-segmented company. Copernican Journal of Finance \& Accounting, $7(1), 21-33$.

Mom, T., \& Fourné, S., \& Jansen, J. (2015). 'Managers' work experience, ambidexterity, and performance: The contingency role of the work context. Human Resource Management, 54(1), 133-153.

Montesinhos, J. E. (1993). El princípio del devengo: Algumas reflexiones en torno a su concepto y aplicacion en contabilidad. Associación Española de Contabilidade y Adminsitración, 36, 683-772.

Mukhametzyanov, R., \& Nugaev, F. (2016). Financial statements as an information base for the analysis and management decisions. Journal of Economics and Economic Education Research, 17(2), 47-54.

Murphy, G., Trailer, J., \& Hill, R. (1996). Measuring research performance in entrepreneurship research. Journal of Business Research, 36(1), 15-23.

Nonaka, I, (1991). The knowledge-creating company. Havard Business Review, 69, 96-104.

Özturk, B., \& Özçelík, F. (2014). Financial performance evaluation of firms in Bist chemical petroleum plastic sector by using an integrated multi-criteria decision-making method. Journal of Economics, Sociology \& Politics, 11(2), 34-62.

Regulation of the European Parliament no. $1606 / 2002$ and of the Council of 19 July.
Sá, A. L. (1998). História geral e das doutrinas da contabilidade (2a ed.). Vislis Editores, Lisbon.

Saaty, T. (1996). Decision making with dependence and feedback. In nome do autor do livro. The analytic network process: the organization and prioritization of complexity (informar página inicial e final do capitulo). RWS Publications: Pittsburgh.

Schwartz, M. (2016). Ethical decision-making theory: An integrated approach. Journal of Business Ethics, 139(4), 755-776.

Smith, S. S. (2017). Accounting analytics: An opportunity for stakeholder reporting and improved policy decisions. International Research Journal of Applied Finance, 8(7), 429-442.

Staubus, G. L. (2000). The Decision-usefulness theory of accounting: A Limited history. New York: Garland Publishing.

Sorensen, B., \& Stuart, E. (2000). Age, obsolescence, and organizational innovation. Academy of Management Journal, 25(6), 121-132.

Watts, R. L., \& Zimmerman, J. L. (1978). Towards a positive theory of the determination of accounting standards. The Accounting Review, 3(1), 112- 134 .

Wheelen, T. L., \& Hunger, J. D. (2004). Strategic management and business policy (9th ed.). Upper Saddle River, NJ.: Pearson Education.

Tang, Y.-C. and Liu, Y.-J. (2016). Beyond objective knowledge: The moderating role of field dependence-independence cognition in financial decision making. Social Behavior and Personality, 44(3), 519-528.

Zehir, C., \& Özsahin, M. (2008). A field research on the relationship between strategic decisionmaking speed and innovation performance in the case of Turkish large-scale firms. Management Decision, 46(5), 709-724. 


\section{Authors:}

1. Catarina Libório Morais Cepêda, Master in Accounting and Finance, Polytechnic of Porto, Accounting and Business School, Porto, Portugal.

E-mail:catarina_cepeda@hotmail.com

ORCID

(iD) 0000-0002-3911-0894

2. Albertina Paula Monteiro, PhD in Marketing and Strategy, School of Economics and Management, University of Minho, Minho, Portugal.

E-mail: amonteiro@iscap.ipp.pt

ORCID

(iD 0000-0002-2146-9807

\section{Contribution of each author}

\begin{tabular}{lcc}
\hline Contribution & $\begin{array}{c}\text { Catarina } \\
\text { Cepêda }\end{array}$ & $\begin{array}{c}\text { Albertina } \\
\text { Monteiro }\end{array}$ \\
\hline 1. Definition of research problem & $\sqrt{ }$ \\
2. Development of hypotheses or research questions (empirical studies ) & $\sqrt{ }$ & $\sqrt{ }$ \\
3. Development of theoretical propositions ( theoretical Work) & $\sqrt{ }$ \\
4. Theoretical foundation/ Literature review & $\sqrt{ }$ \\
5. Definition of methodological procedures & $\sqrt{ }$ \\
6. Data collection & $\sqrt{ }$ \\
7. Statistical analysis & $\sqrt{ }$ \\
8. Analysis and interpretation of data & $\sqrt{ }$ \\
9. Critical revision of the manuscript & $\sqrt{ }$ \\
10. Manuscript Writing & $\sqrt{ }$ \\
11. Other (please specify which) & $\sqrt{ }$ \\
\end{tabular}

